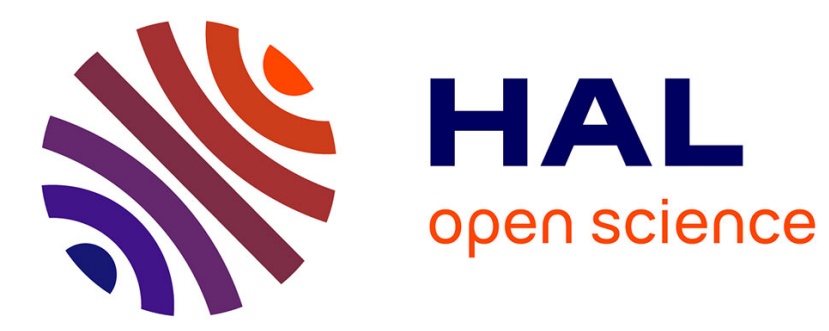

\title{
First paleomagnetic evidence for rotation of the Ionian Zone of Albania
}

\author{
F. Speranza, C. Kissel, I. Islami, A. Hyseni, C. Laj
}

\section{To cite this version:}

F. Speranza, C. Kissel, I. Islami, A. Hyseni, C. Laj. First paleomagnetic evidence for rotation of the Ionian Zone of Albania. Geophysical Research Letters, 1992, 19 (7), pp.697-700. 10.1029/92GL00575 . hal-03584046

\author{
HAL Id: hal-03584046 \\ https://hal.science/hal-03584046
}

Submitted on 22 Feb 2022

HAL is a multi-disciplinary open access archive for the deposit and dissemination of scientific research documents, whether they are published or not. The documents may come from teaching and research institutions in France or abroad, or from public or private research centers.
L'archive ouverte pluridisciplinaire HAL, est destinée au dépôt et à la diffusion de documents scientifiques de niveau recherche, publiés ou non, émanant des établissements d'enseignement et de recherche français ou étrangers, des laboratoires publics ou privés. 


\title{
FIRST PALEOMAGNETIC EVIDENCE FOR ROTATION OF THE IONIAN ZONE OF ALBANIA
}

\author{
F. Speranza ${ }^{1}$, C. Kissel ${ }^{1}$, I. Islami ${ }^{2}$, A. Hyseni ${ }^{2}$ and C. Laj ${ }^{1}$
}

\begin{abstract}
A paleomagnetic study of 170 samples obtained from 15 sites from Cretaceous, Eocene and Oligocene sedimentary rocks documents a $\sim 45^{\circ}$ clockwise rotation of the Albanian Ionian zone. This rotation is certainly post-Eocene and most probably post-Oligocene. These results show that the entire Ionian zone has undergone a semi rigid rotation about a pole of rotation situated farther north than previously believed.
\end{abstract}

\section{Introduction}

There is now a general agreement that the edification of the Dinaric and Albano-Hellenic segments results from a large-scale, westward directed thrusting over Triassic evaporitic horizons, responsible for the emplacement of nappe sheets over the Apulian platform. Two major transverse tectonic features are observed in Albania. The Scutari-Pec "transversal" situated in the northern part of Albania corresponds to the limit between the Dinarides and the Albano - Hellenides. This area is characterized by a change in the orientation of the main structures from N120 in the Dinarides to $\mathrm{N} 150$ in the Albano-Hellenides. It has been interpreted as a paleo-transform fault because the Albanian ophiolitic nappe is shifted about $100 \mathrm{~km}$ westward with respect to its Dinaric equivalent. The disappearance of the Albanian Alps zone in the south, yields convincing evidence that the Scutari-Pec zone represents a major crustal discontinuity. Further south, between Tirana and the area studied in this work, another tectonic feature is clearly visible: the Diber-Elbasan-Vlore transversal. It is parallel to the Scutari-Pec transversal but is not associated with a change in the structural trends. Slight variations in the trend of the Ionian structures can be observed, but they never exceed $10^{\circ}$.

Paleomagnetic studies may contribute to a better understanding of the evolution of this region by providing a geodynamical framework in which the original structural configuration can be investigated. Paleomagnetic data obtained in the Greek Ionian and Preapulian zones have provided evidence for a large clockwise rotation which accurred in two phases of about $25^{\circ}$ each during the Middle Miocene and the Plio-Pleistocene [Laj et al., 1982; Horner and Freeman, 1983; Kissel et al., 1985].

In this letter we report on the first paleomagnetic results obtained from the Cenozoic sedimentary formations outcropping in the Ionian zone of Albania. These results extend northward the results obtained in northwestern Greece

\footnotetext{
Centre des Faibles Radioactivités, Laboratoire mixte CNRS/CEA

${ }^{2}$ Fakulteti i Gjeologjise dhe i Minierave
}

Copyright 1992 by the American Geophysical Union. and constitute a necessary first step in the investigation of possible changes in the rotational pattern south and north of the Scutari-Pec zone.

\section{Geological Setting and Sampling.}

The Ionian zone of Albania is constituted of sedimentary sequences identical to the ones existing in northwestern Greece. The Mesozoic sequence is overlain by pelagic Paleocene and Eocene marly limestones with cherty lenses. The limestones are very fine grained and show alternances of different colours, pink, grey, blue and white. They are very similar to the Scaglia formation wellknown in Italy. From Eocene to Middle Miocene (Serravallian) times, mainly flysch formations were deposited. The sedimentary cycle of the Ionian zone finished during the Tortonian, with the deposition of thick and coarse molasse beds. From the late Serravallian to the early Tortonian, the main tectonic events in the Ionian zone gave rise to regional folds trending $\mathrm{N} 150$ and to the emplacement of large, southwestward directed thrusts. Other minor compressive events occurred later, affecting the transgressive Tortonian molasses. Because of the thrusts, the western limbs of the folds are better developed than the eastern ones and sometimes outcrop as monoclines.

Mainly Eocene marly limestones and Oligocene finegrained flysch sections were sampled for the paleomagnetic study. The location of the sampling sites is shown in Figure 1. The three Oligocene sites are located in the western limb of the Permet NW-SE trending syncline, i.e. the NE limb of the Kercyre box fold. One of them (AL01) is of middle-upper Oligocene age, the two others of lower Oligocene. The Eocene sites were sampled mainly along the Gjirokaster structure, except two sites sampled in the Kelcyre anticline and one along the coast, on the eastern limb of the Sarande anticline. A lower Cretaceous site was also sampled in the western limb of the Gjirokaster structure. This structure represents the northern continuation of the Botzara syncline in northwestern Greece, where Oligocene flysch and Eocene limestone sections have been previously studied [Homer and Freeman, 1983; Kissel et al. 1985]. It is a major structure and any data about its rotation are significant for the entire region. Moreover, as the other folds of the same area, the axis of the structure is virtually horizontal, so that the simple tilt correction used in paleomagnetism can be safely used.

The cores were drilled and oriented with standard paleomagnetic techniques. Both a sun and a magnetic compass were used to orient the cores. A total of 170 cores were collected from 15 sites. Each core yielded 2-3 specimens allowing laboratory studies of the magnetic mineralogy and the characteristic remanent magnetization (ChRM).

\section{Magnetic Mineralogy}

The nature of the magnetic minerals was investigated for at least one sample per site. Stepwise acquisition of the 


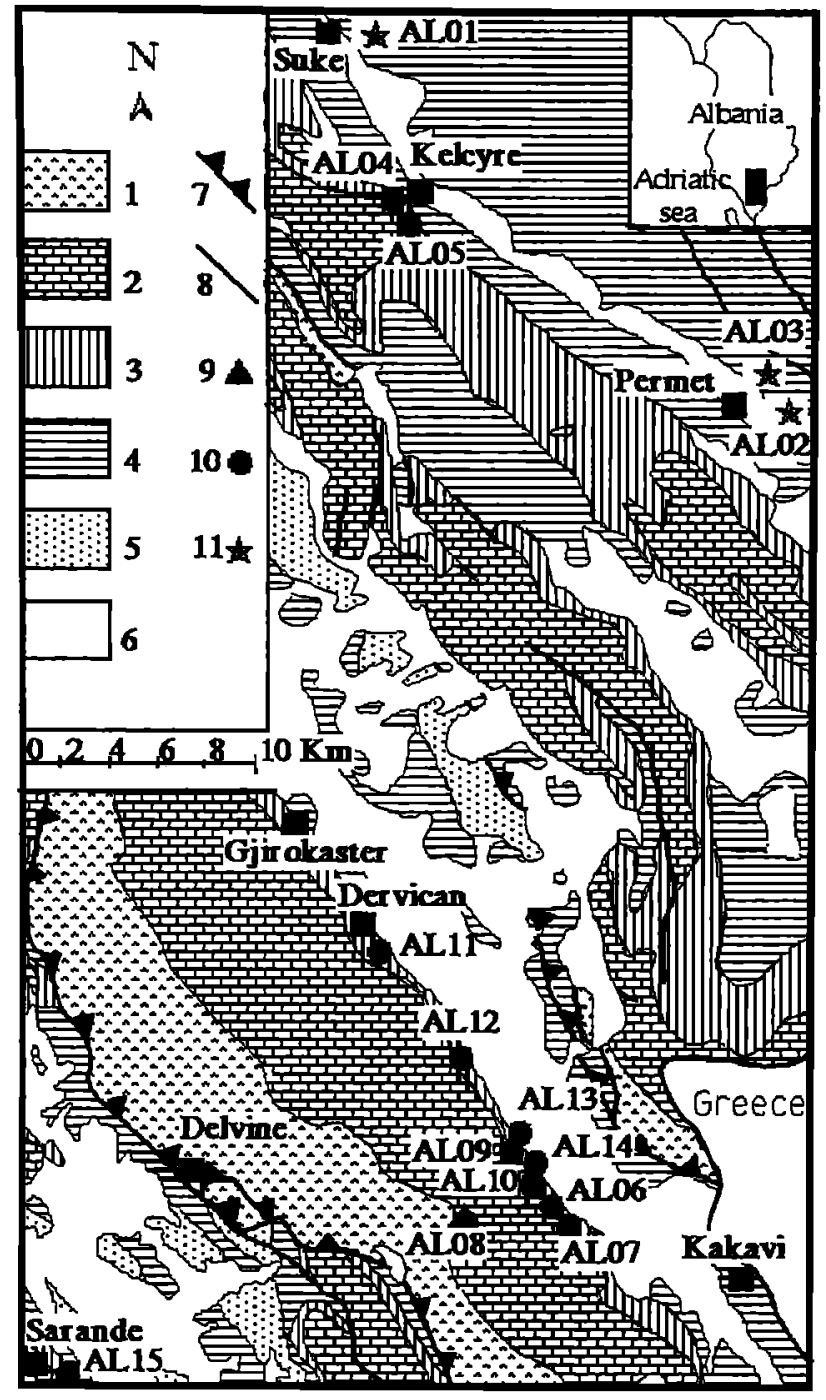

Fig. 1. Geological scheme of the studied area. Geological formations: 1 - Triassic-Jurassic; 2 - Cretaceous-Palaeocene; 3 - Eocene; 4 - Oligocene; 5 - Aquitanian-Tortonian; 6 Recent deposits. Structural features: 7 - Thrust faults; 8 Faults. Paleomagnetic sites: 9 - Cretaceous; 10 - Eocene; 11 Oligocene.

isothermal remanent magnetization (IRM) indicates that about $85 \%$ and virtually $100 \%$ of the saturation is acquired in fields lower than $0.3 \mathrm{~T}$ for limestones and flysch respectively. In the limestones the increase of the IRM beyond $0.3 \mathrm{~T}$ indicates the presence of a higher coercitivity mineral, possibly haematite. Haematite forming soon after deposition has already been observed in Scaglia type limestones [Channell et al., 1982]. As the highest observed blocking temperatures are of the order of 450 to $630^{\circ} \mathrm{C}$, the main fraction of the remanence is most probably carried by magnetite.

Additional evidence was obtained by analyzing small chips of the samples with a Micromag model 2900 alternating gradient force magnetometer. A typical hysteresis loop is shown in Figure 2a. There is a large diamagnetic contribution due to the calcite contents, clearly shown by the negative slopes at high fields. After substraction of this contribution, the saturation magnetization (Ms), the saturation remanence

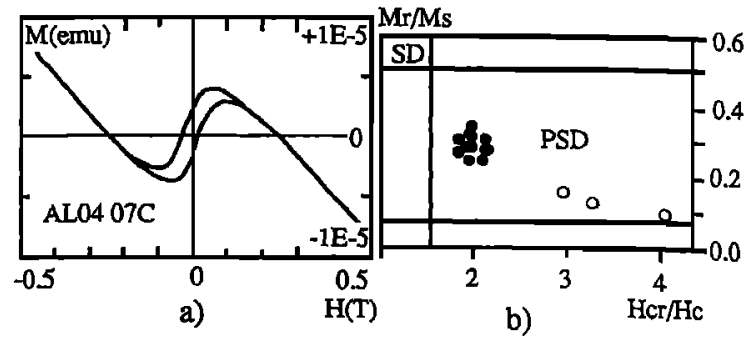

Fig. 2. a): Hysteresis loop of an Eocene marly limestone sample. b): $\mathrm{Mr} / \mathrm{Ms}$ versus $\mathrm{Hcr} / \mathrm{Hc}$ diagram from Day et al. 1977. $\bullet=$ Cretaceous-Eocene limestones;O=Oligocene flysch.

(Mr), the coercitive field $(\mathrm{Hc})$ and the coercitivity of remanence ( $\mathrm{Hcr}$ ) were calculated. The ratios of these parameters (Figure 2b) indicate that the magnetic properties of the samples are mainly carried by pseudo-single domain magnetite [Day et al., 1977], and that magnetic grains of the limestone samples all show very similar characteristics.

Thermal demagnetization, with 10-16 steps from room temperature to the limit of reproducible results $\left(450\right.$ to $\left.630^{\circ} \mathrm{C}\right)$ was used throughout. The measurements were made in a shielded room with a $2 \mathrm{G}$ 3-axes cryogenic magnetometer. The low field susceptibility, used to monitor possible changes in the magnetic minerals during the thermal treatment, was stable within a factor of two over the interval 20 to $580^{\circ} \mathrm{C}$.

Two different behaviours of the remanent magnetization of the samples were observed during demagnetization. For some samples, apart from a small viscous component removed below $200-250^{\circ} \mathrm{C}$, orthogonal demagnetization diagrams isolate a single stable component of magnetization (Figure 3a). Other samples are characterized by two antipodal directions of magnetization with largely overlapping blocking temperature spectra. This behaviour has also been observed in the Scaglia limestones in Italy [Channel et al., 1982], and in the "Rosso Ammonitico" marls in Greece [Surmont, 1989]. The demagnetization data of these samples perfectly fit on great circles. Some of the sites yielded samples all

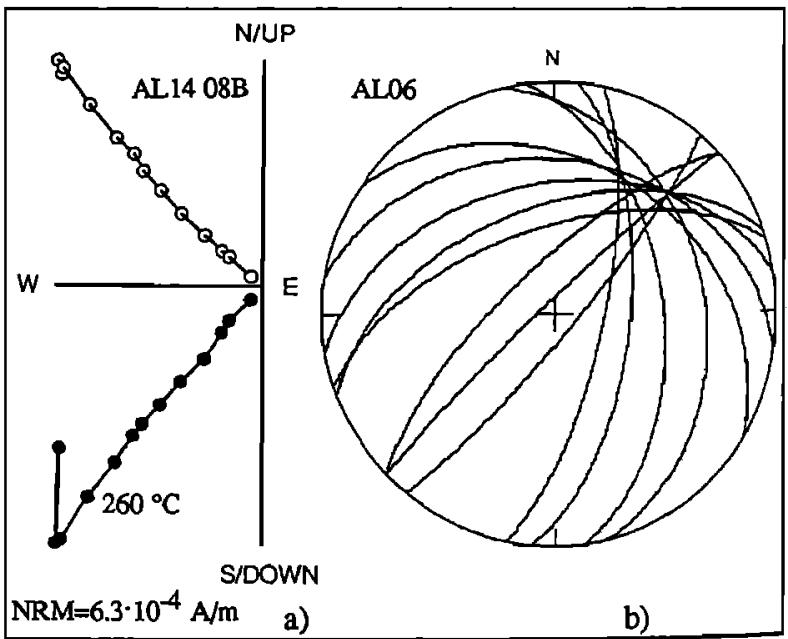

Fig. 3. a): Typical thermal demagnetization diagram ( $\bullet=$ horizontal projection; $\mathrm{O}=$ vertical projection) of an Eocene marly limestone sample. b): Equal-area lower hemisphere projection of great circles obtained from an Eocene site. 
characterized by one or the other of the two behaviours (Figure 3b). In other sites, samples belonging to one or the other of the two types coexist at different stratigraphic levels.

The mean direction of the ChRM was obtained either with Fisher's statistics or with the method described by McFadden and McElhinny [1988]. In most case there is a good withinsite grouping of the data $\left(\alpha_{95}<10\right.$; Table1). Only the Cretaceous site has a large $\alpha 95$, but this site has a very weak magnetization ( 4 to $70.10^{-6} \mathrm{~A} / \mathrm{m}$ ) and only 4 samples gave reliable results.

When samples of normal and reverse polarities coexist in the same site, their ChRM are perfectly antipodal. Antipodality is also observed when the mean directions from reverse and normal sites are considered (Tablel, Figure 4). This is evidence for good magnetic stability and satisfactory cleaning. One site (AL07) was sampled in a small-scale fold with different bedding attitudes for the different samples. The within-site scatter is significantly smaller after bedding correction than before it $\left(n=10, k_{1} / k_{2}=3.6, F(18,18) 1 \%=\right.$ 3.05). At a regional scale, no fold test could be obtained, because the sites were sampled on the same limb of the structures. However, the scatter of the data decreases significantly (at the $1 \%$ significance level) after tectonic correction $\left(\mathrm{N}=15, \mathrm{~K}_{1} / \mathrm{K}_{2}=2.78, \mathrm{~F}(28,28) 1 \%=2.50\right)$. In summary, all the laboratory and field tests show that the sampled formations are suitable for a paleomagnetic study.

\section{Paleomagnetic Results and Discussion}

The results obtained from the 15 sites are reported in Table 1 and in Figure 4. The majority of the sites, of Eocene age,

TABLE 1. Paleomagnetic directions from 15 sites in Ionian zone of southern Albania

\begin{tabular}{lcrrrrrrr}
\hline Site & Age & $\mathrm{N}$ & $\mathrm{D}$ bc & $\mathrm{I}_{\mathrm{bc}}$ & $\mathrm{D}_{\mathrm{ac}}$ & $\mathrm{I} a \mathrm{c}$ & $\mathrm{K}$ & $\alpha_{95}$ \\
\hline AL01 & $\mathrm{O} 1$ & $5,1^{*}$ & $69^{\circ}$ & $52^{\circ}$ & $64^{\circ}$ & $34^{\circ}$ & 70.5 & 8.2 \\
AL02 & $\mathrm{O}$ & $7,3^{*}$ & $201^{\circ}$ & $-60^{\circ}$ & $208^{\circ}$ & $-31^{\circ}$ & 26.6 & 9.6 \\
AL03 & $\mathrm{O}$ & $0,11^{*}$ & $217^{\circ}$ & $-19^{\circ}$ & $217^{\circ}$ & $-16^{\circ}$ & 112 & 4.3 \\
AL04 & $\mathrm{E}$ & $12,0^{*}$ & $100^{\circ}$ & $80^{\circ}$ & $53^{\circ}$ & $48^{\circ}$ & 76.6 & 5.0 \\
AL05 & $\mathrm{E}$ & $9,2^{*}$ & $83^{\circ}$ & $79^{\circ}$ & $46^{\circ}$ & $42^{\circ}$ & 37.2 & 7.6 \\
AL06 & $\mathrm{E}$ & $0,12^{*}$ & $32^{\circ}$ & $50^{\circ}$ & $36^{\circ}$ & $36^{\circ}$ & 226 & 2.9 \\
AL07 & $\mathrm{E}$ & $10,0^{*}$ & $223^{\circ}$ & $-43^{\circ}$ & $223.5^{\circ}$ & $-37^{\circ}$ & 59.7 & 6.3 \\
AL08 & $\mathrm{K}$ & $3,1^{*}$ & $20^{\circ}$ & $59^{\circ}$ & $31.5^{\circ}$ & $32^{\circ}$ & 37.7 & 16.1 \\
AL09 & $\mathrm{E}$ & $8,2^{*}$ & $210.5^{\circ}$ & $-62^{\circ}$ & $219^{\circ}$ & $-43^{\circ}$ & 53.5 & 6.7 \\
AL10 & $\mathrm{E}$ & $7,3^{*}$ & $42.5^{\circ}$ & $51.5^{\circ}$ & $42^{\circ}$ & $30.5^{\circ}$ & 38.8 & 8.0 \\
AL11 & $\mathrm{E}$ & $11,0^{*}$ & $227^{\circ}$ & $-56^{\circ}$ & $230.5^{\circ}$ & $-32^{\circ}$ & 88.8 & 4.9 \\
AL12 & $\mathrm{E}$ & $8,2^{*}$ & $210^{\circ}$ & $-61^{\circ}$ & $221^{\circ}$ & $-43^{\circ}$ & 132 & 4.3 \\
AL13 & $\mathrm{E}$ & $9,2^{*}$ & $41^{\circ}$ & $62^{\circ}$ & $46^{\circ}$ & $38^{\circ}$ & 92.2 & 4.8 \\
AL14 & $\mathrm{E}$ & $8,0^{*}$ & $219^{\circ}$ & $-58^{\circ}$ & $222^{\circ}$ & $-35.5^{\circ}$ & 118 & 5.1 \\
& & $8,0^{*}$ & $347^{\circ}$ & $70^{\circ}$ & $31^{\circ}$ & $45^{\circ}$ & 94.6 & 5.7 \\
AL15 & $\mathrm{E}\left\{2,0^{*}\right.$ & $188^{\circ}$ & $-71^{\circ}$ & $219^{\circ}$ & $-41^{\circ}$ & $/$ & $/$ \\
& & $10,0^{*}$ & $351.5^{\circ}$ & $71^{\circ}$ & $33^{\circ}$ & $44^{\circ}$ & 89.7 & 5.1 \\
\hline
\end{tabular}

$\mathrm{N}$ : number of stable directions and of great circles (*); declination and inclination are calculated before $\left(\mathrm{Dbc}_{\mathrm{bc}}, \mathrm{I}_{\mathrm{bc}}\right)$ and after $\left(D_{a c}, I_{a c}\right)$ bedding correction was applied. Site AL15 containing samples of both polarities is indicated and the polarity assigned to this site is the one of the majority of the samples.

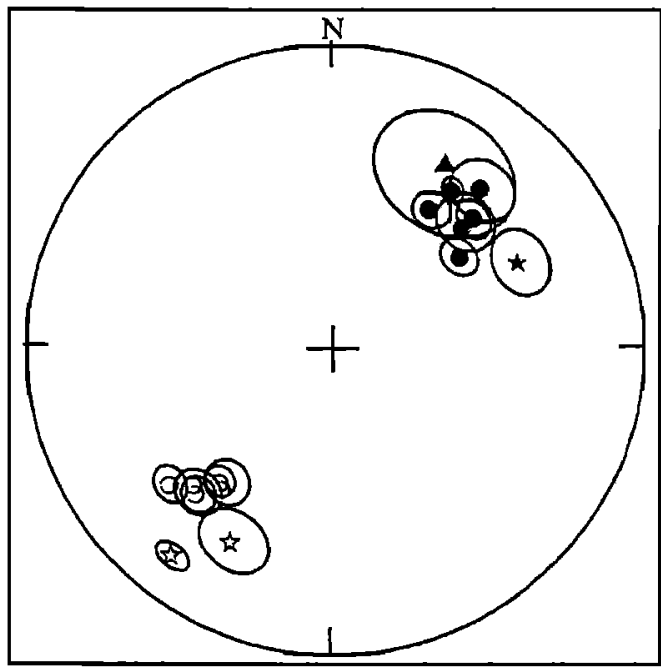

Fig. 4. Equal-area projection of the mean directions of magnetization obtained from each site, with relative $95 \%$ confidence circles. Full symbols=downward magnetization directions. Open symbols=upward magnetization directions. The symbols are the same as for Figure 1.

yield a precise regional mean paleomagnetic direction defined by: $N=11 ; D=43^{\circ} ; I=39^{\circ} ; \alpha_{95}=4^{\circ}$.

Because the studied region is located at the eastern boundary of the Apulian platform, it seems reasonable to refer our data to the African paleomagnetic poles. The obtained mean direction corresponds to a clockwise rotation with a mean amplitude of 43 or $46^{\circ}$ depending on the choice of the Eocene reference pole [Van der Voo and French, 1974; Westphal et al., 1986].

Only three Oligocene sites have been studied and their paleomagnetic directions are significantly more scattered than those obtained from the limestones. However, when the mean direction calculated from these three sites $\left(\mathrm{D}=42^{\circ} ; \mathrm{I}=28^{\circ}\right)$ is referred to the available Oligocene poles [Schult, 1974; Westphal et al., 1986], it corresponds to a $\sim 40^{\circ}$ clockwise rotation, very similar to the one observed in the Eocene.

Finally, the direction obtained from the lower Cretaceous site referred to the poles proposed by Westphal et al. [1986] and by Besse and Courtillot [1991] corresponds to a clockwise rotation of about $55^{\circ}$ and $65^{\circ}$ respectively. We are well aware that no definitive conclusion can be drawn from this single site, the mean direction of which is poorly defined $\left(\alpha_{95}=16^{\circ}\right)$. Additional Cretaceous data are thus necessary to better constrain the lower Cretaceous to Oligocene evolution of the rotation.

These first paleomagnetic results show that the southern part of the Ionian Albanian zone has undergone a clockwise rotation of about $45^{\circ}$. This rotation is certainly post-Eocene and probably post Oligocene. This last point has to be confirmed by further study of Oligocene sites. From a regional point of view, the rotation has been observed coherently from East to West, in three different structures separated by thrusts. This implies that these thrusts have not introduced any differential rotation. Moreover, the absence of any shear zone in the studied area rules out the possiblity of in-situ block rotations. In addition, the observed rotation is much larger than the local variations of the fold axes. We can 
thus conclude that it is representative of the movement of the Ionian zone in southern Albania.

This rotational behaviour is identical to the one already observed from the same formations in northwestern Greece [Horner and Freeman, 1983; Kissel et al., 1985] suggesting that the Ionian zone has undergone an almost rigid clockwise rotation of about $45^{\circ}$ as a whole, from the Gulf of Corinth to about the northern end of the emerged part of the Ionian zone, the Elbasan-Tirana region. This coherent behaviour is consistent with the continuity of the trend of the geological structures all over the Ionian zone. The observed rotation is also consistent with the one observed recently in the Albanian internal zones [Mauritsch et al., 1991].

An important geological consequence of these new data is that the "pivot zone" is located further north than believed on the basis of the previous studies in Greece. In Le Pichon and Angelier original model [1979] it was assumed that the rotation extended only as far as north as Akarnania with a rotation pole in the southern Adriatic sea. Then the paleomagnetic data have shown that Epirus has also undergone the same rotation, pushing the pivot zone northward [Horner and Freeman, 1983; Kissel et al., 1985]. The present study implies that the pivot zone is even further north. Assuming it to be in the Tirana-Elbasan region, and a $45^{\circ}$ rigid rotation, the minimum horizontal displacement is evaluated as $250 \mathrm{~km}$ at the Corinth Gulf and about $110 \mathrm{~km}$ at the Albanian-Greek border.

This paleomagnetic study is the first one which gives informations about the rotational evolution of the external zones of Albania. It confirms that the southern part of Albania has behaved as northwestern Greece and implies that the region concerned by the change between counterclockwise and clockwise rotations is located further north, towards the Scutari-Pec transverse.

Acknowledgments. This work is part of a cooperation between the CFR, the University Paris VI and the Faculty of Geology and Mining of Tirana. We thank Mr. Grazhdani, Dean of this faculty, for his constant help in solving all the administrative and logistic points. We also thank S. Pêllumbi for his invaluable help in the field, E. Blanchard for some measurements in the laboratory, M. Bonneau for some micropaleontological determinations, A. Frasheri for critical reading of the manuscript, and $H$. Mauritsch for helpful discussions. The financial support for the field trip has been given by the CEA and the Fakulty of Geology and Mining of Tirana. This is contribution $n^{\circ} 1271$ from the CFR

\section{References}

Besse, J. and V. Courtillot, Revised and Synthetic Apparent Polar Wander Paths of the African, Eurasian, North American and Indian Plates, and True Polar Wander Since 200 Ma, J. Geophys. Res., 96, 4029-4050, 1991.
Channell, J. E. T., R. Freeman, F. Heller, and W. Lowrie, Timing of diagenetic haematite growth in red pelagic limestones from Gubbio (Italy), Earth and Plan. Sci. Lett., 58, 189-201,1982.

Day, R., M. Fuller, and V. A. Schmidt, Hysteresis properties of titanomagnetites: grain size and compositional dependance, Phys, Earth and Planet. Int., 13, 260-267, 1977.

Horner, F. and R. Freeman, Palaeomagnetic evidence from pelagic limestones for clockwise rotation of the Ionian zone, western Greece, Tectonophysics, 98, 11-27, 1983.

Kissel, C., C. Laj, and C. Muller, Tertiary geodynamical evolution of Northwestern Greece, palaeomagnetic results, Earth Planet. Sci. Lett., 72, 190-204, 1985.

Laj, C., M. Jamet, D. Sorel, and J. P. Valente, First paleomagnetic result from Mio-Pliocene series of the Hellenic sedimentary arc, Tectonophysics, 86, 45-67,1982.

Le Pichon, X. and J. Angelier, The Hellenic Arc and Trench system: a key to the neotectonic evolution of the eastern mediterranean area, Tectonophysics, 60, 1-42, 1979.

Mauritsch, H. J., R. Scholger, and P. Alikay, Paleomagnetic results of Albania (U. Cretaceous-Eocene) and their tectonic significance in the frame of the AlpineMediterranean tectonic evolution, paper presented at the IAGA meeting for the XX General Assembly of the IUGG in Vienna, Aug. 11 to 24, 1991.

McFadden, P. L. and M. W. McElhinny, The combined analysis of remagnetization circles and direct observations in paleomagnetism, Earth and Plan. Sci. Lett., 87, 161$172,1988$.

Schult, A., Paleomagnetism of Tertiary volcanic rocks from the Ethiopian southern plateau and the Danakils block, I Geophys., 50, 16-22, 1974.

Surmont, J., Paléomagnétisme dans les Hellénides intemes: analyse des aimantations superposées par la méthode des cercles de réaimantation, Can. J. Earth Sci., 26, 24792494, 1989.

Van der Voo, R. and R.B. French, Apparent polar wandering for the Atlantic-bordering continents: Late Carboniferous to Eocene, Earth Sci. Rev., 10, 99-119, 1974.

Westphal, M., M. L. Bazhenov, J. P. Lauer, D. M. Pechersky, and J. C. Sibuet, Paleomagnetic implications on the evolution of the Tethys belt from the Atlantic ocean to the Pamirs since the Triassic, Tectonophysics, 123. 37-82, 1986.

C. Kissel, C. Laj, F. Speranza, Centre des Faibles Radioactivités, Laboratoire mixte CNRS/CEA, Avenue de la Terrasse, 91198 Gif-sur-Yvette Cedex, France.

A. Hyseni and I. Islami, Fakulteti i Gjeologjise dhe $i$ Minierave, Tirana, Albania.

(Received January 24, 1992; revised March 9, 1992; accepted March 9, 1992.) 